\title{
Article \\ Organised Interests in the Energy Sector: A Comparative Study of the Influence of Interest Groups in Czechia and Hungary
}

\author{
Brigitte Horváthová * and Michael Dobbins \\ Faculty of Social Sciences, Goethe University of Frankfurt, 60629 Frankfurt am Main, Germany; \\ E-Mails: horvathova@em.uni-frankfurt.de (B.H.), dobbins@soz.uni-frankfurt.de (M.D.) \\ * Corresponding author
}

Submitted: 15 October 2018 | Accepted: 5 February 2019 | Published: 28 March 2019

\begin{abstract}
In this article, we explore civil society mobilisation and the impact of organised interests on the energy policies of two postcommunist countries-Hungary and Czechia-and specifically nuclear energy. Drawing on numerous hypotheses from the literature on organised interests, we explore how open both political systems are for civil society input and what interest group-specific and socio-economic factors mediate the influence of organised interests. Based on the preference attainment method, our case studies focus on the extent to which organised interests have succeeded bringing nuclear energy legislation in line with their preferences. We find that while both democracies are open to civil society input, policy-making is generally conducted in state-industrial circles, whereby anti-nuclear and renewable energy advocates are at best able to make minor corrections to already pre-determined policies.
\end{abstract}

\section{Keywords}

civil society; Czechia; energy policy; Hungary; interest groups; nuclear energy

Issue

This article is part of the issue "EU Energy Policy: Towards a Clean Energy Transition?", edited by Kacper Szulecki and Dag Harald Claes (University of Oslo, Norway).

(C) 2019 by the authors; licensee Cogitatio (Lisbon, Portugal). This article is licensed under a Creative Commons Attribution 4.0 International License (CC BY).

\section{Introduction}

In this article, we explore civil society mobilisation in two post-communist countries, Czechia and Hungary, while specifically analysing the impact of organised interests on nuclear energy policy-making. The post-communist political transformation is indeed a well-studied phenomenon. In the early transformation phase, most studies focussed primarily on the re-design of political institutions and constitutional arrangements (Hellman, 1998; Ramet, 2010; Stark \& Bruszt, 1998). More recently though, numerous analyses addressed civil society mobilisation (Carmin, 2010; Fink-Hafner, 2011; Howard, 2003; Pérez-Solórzano Borragán, 2006) and the development of interest intermediation systems (Avdagic, 2005; Pleines, 2011). This is a crucial aspect of democratisation because organised interests-as conveyors of inputs into the political process-can be regarded as a precondition of democracy (Dahl, 1971). While organised interests indeed may have a legitimising effect by injecting citizens' preferences into decision-making, the democratic process may also be undermined when special interests continuously assert their demands to the detriment of others (Dür \& De Bièvre, 2007). Moreover, democracy may be endangered by weak or inefficient channels of interest intermediation. Crouch (2004) defines this condition as a "post-democratic" legitimation crisis, hence a situation in which institutions exist formally, but civil society no longer shapes policies.

Organised interests are burdened with a difficult legacy in Central and Eastern Europe (CEE). Under socialism, civil society activity was largely channelled through communist parties, which in turn converted any pre-existing interest associations into their own ap- 
pendages (Kubik, 2005). The oppression of civic participation outside the party has reinforced the view that post-communist organised interests remain weak and fragmented (Howard, 2003). For example, Ágh (1996) speaks of a "missing middle", thus an absence of effective links between societal interests, the state and market institutions. In contrast, Fink-Hafner (1998) contends that civil society is being reinvented, a view backed by numerous analyses on organisational membership (Petrova \& Tarrow, 2007) and parliamentary representation (Fink-Hafner, 2011). Along these lines, Guasti (2016) argues that civil society has emerged as an "arena for contestation of governmental policies and ideational alternative to national-conservative ideologies" (Guasti, 2016, p. 229).

In either case, interest organisations constitute an important field of research regarding the functioning of democracy, in particular in CEE. Due to the historical oppression of democratic mobilisation and the communist system's heavy burden on civil society, it is crucial to assess-almost three decades after the fall of the Berlin Wall-whether and which organised interests have shaped post-communist policies. Against this background, this article focusses on the design of interest intermediation structures and, specifically, the actual influence of organised interests on recent nuclear energy legislation in Hungary and Czechia.

Energy is a highly relevant policy area in CEE and beyond, as secure, cost-effective and environmentally friendly energy is a precondition for functioning societies. CEE countries generally share a legacy of environmental neglect and inefficient energy usage. While the postcommunist transformation, European integration and, notably, the bankruptcy of many energy-intensive industries indeed resulted in a reduction of usage, CEE is still characterised by limited natural resources, increasing prices as well as dependence on Russian energy (Aalto, Nyyssönen, Kojo, \& Pal, 2017; Binhack \& Tichý, 2012). Thus, CEE countries are simultaneously aiming to promote renewable, safe, and diversified energy sources, increase efficiency and form regional markets.

Drawing on the well-established literature on interest groups (Dür, 2008; Eising, 2008; Klüver, 2013), we explore the following research question: How open are post-communist political systems for civil society input and what factors condition the influence of interest groups on nuclear energy policy? Taking inspiration from Kitschelt's (1986) study on anti-nuclear movements in western democracies, we assess the accessibility of postcommunist political systems for interest groups and highlight the factors which have increased or hampered the impact of anti-nuclear movements.

We aim to modestly advance three bodies of research-the literature on post-communist civil society, research on interest groups in general, and research focussing on CEE energy policy. Substantively we address the national energy strategies laid out in the Czech State Energy Policy (SEP; Ministerstvo prümyslu a ob- chodu, 2015) and Hungarian National Energy Strategy (NES) 2030 (Nemzeti Energiastratégia, 2030) from 2012 (Nemzeti Fejlesztési Minisztérium, 2012). The timeframe of analysis is from 2011 to 2018, whereby the Fukushima disaster is a turning point which compelled many countries to reassess nuclear energy and the viability of their energy mix.

Next we outline pre-existing studies, before presenting our theoretical framework and methodological approach. In our empirical analysis, we first discuss the overall energy policy background and identify key interest groups. We then assess to what extent they pushed relevant legislation in their preferred direction, before identifying the key factors that condition their impact. Finally, we elaborate on the modes of interest intermediation by engaging with classical concepts of statism, pluralism and corporatism (Fink-Hafner, 2011; Siaroff, 1999). Our analysis reveals that statist arrangements with some corporatist elements have emerged, whereby governments strongly incorporate nuclear energy providers into official policy-making, thus resulting in formidable state-industry alliances to the detriment renewable energies groups.

\section{Post-Communist Civil Society and Energy Policy-Making}

Political science is rich in studies on civil society and organised interests. However, they focus largely on western countries (Baumgartner, 2009; Binderkrantz, Christiansen, \& Pedersen, 2014; Mahoney, 2007), while organised interests and lobbying in the European Union (EU) have increasingly attracted attention (Klüver, 2009; Schneider \& Baltz, 2003). Political scientists have also more recently significantly enhanced our understanding of the determinants of lobbying success (Binderkrantz \& Rasmussen, 2015; Bunea, 2013; Klüver, 2013).

Although CEE has largely been overlooked by such research, the 2000s gave rise to numerous studies on civil society in post-communist democracies. Most notably, Howard (2003) paints an ambivalent picture of civil society in CEE by arguing that it neither endangers the democratic system itself nor leads to the development of anti-democratic activities. Fundamentally, he contends that mistrust in the political process has led to low civic participation (Howard, 2003). Pérez-Solórzano Borragán (2006) also highlights two reasons for the low civic participation: historical legacies and disappointment with the regime transformation. The former refers to the oppression of civil society by the communist regime, resulting in suspicion towards the state. Moreover, CEE interest organisations suffer from their lack of experience, organisational capacity, and knowledge of "what civil society is and how it operates" (Pérez-Solórzano Borragán, 2006, p. 138).

In his analysis of the development and regulation of organised interests in CEE, McGrath's (2008) diagnosis is the same: the discouragement of non-partisan civil society engagement and lacking skills and motivation 
of civil society are major impediments to mobilisation (McGrath, 2008). In a seminal article, Vráblíková (2009) finds that the factors determining participation greatly vary between CEE countries. More recently, Fink-Hafner (2011) focussed on relations between interest groups and CEE national parliaments and demonstrated that the weakness of the parliament is frequently interconnected with its level of attractiveness for interest groups (FinkHafner, 2011).

Scholars have also addressed the impact of the EU on individual organised interests (Císař \& Vráblíková, 2013). Guasti, for example, argues that "new norms, ideals and collective understandings" facilitated higher civil participation (Guasti, 2016, p. 230). Her finding of a civil society revival in CEE is also supported by other studies addressing the importance of EU access in transforming the institutional setting for organised interests (Fagan \& Kopecký, 2017; Vándor, Traxler, Millner, \& Meyer, 2017). Yet despite our enhanced understanding of civil society mobilisation, only few authors have assessed its impact on specific policies (for an exception see Gallai, Döme, Molnár, \& Reich, 2015).

\subsection{Energy Policy Research in CEE}

Numerous analyses on CEE energy policy exist (Balmaceda, 2002; Binhack \& Tichý, 2012; Szulecki, Fischer, Gullberg, \& Sartor, 2016; Vlček \& Černoch, 2013), some of which have even addressed organised interests (Carmin, 2010; Tosun \& Schulze, 2015). According to Andersen, Goldthau and Sitter (2017), the main explanation for energy policy choices within these countries is neither the post-communist legacy nor geographical particularities. CEE rather differs regarding attitudes towards energy policy: first, there is little unity on the EU level mainly due to distinct national preferences. Second, differences persist regarding perceptions of priorities and structural obstacles in these countries due to "energy populism, corruption and general incompetence" (Andersen et al., 2017, p. 215).

Balmaceda (2002) analyses the energy-related geostrategic position of CEE between the EU and Russia and argues that the creation of a gas market will positively impact the energy situation in CEE. Binhack and Tichý (2012), however, stress that there is an asymmetric relationship between Czechia and Russia regarding Czechia's dependence on Russian energy, which in turn has been somewhat balanced by the EU's involvement in transnational energy policy-making. Numerous qualitative studies also have elaborated on energy mixes and energy "democracy", several of which include CEE (Szulecki, 2018; Szulecki et al., 2016). Bakos (2001) explored the privatisation and liberalisation of electricity in Hungary, suggesting an asymmetry similar to the already mentioned case of Czechia, while Aalto et al. (2017) conducted a comparative study on Russian-built nuclear reactors in Hungary and Finland as part of Russian "nuclear energy diplomacy".
Regarding Czechia, Frantál and Malý (2017) address community support for nuclear power plant (NPP) expansion. They conclude that the support of two-thirds of Czech society is related to their "general perception of pros of nuclear power" (Frantál \& Malý, 2017, p. 134). Yet radioactive waste is a problematic issue, drawing the concern of municipalities (Ocelík, Osička, Zapletalová, Černoch, \& Dančák, 2017). A rather technical analysis of energy strategies conducted by Minin and Vlček (2018) reveals that the Fukushima accident did not affect nuclear energy usage at all. Osička and Černoch (2017) argue that structural and cultural factors affected pro-nuclear policy-making in Czechia while Ocelík et al. (2017) address the framing of nuclear waste storage places.

Several studies have also focussed on civil society mobilisation in post-communist energy policy-making. In her important contribution on environmental governance in Hungary and Czechia, Carmin (2010) regards resources and knowledge as important assets for organised interests to participate in decision-making processes. Resources are necessary to maintain their activity level while knowledge and expertise are preconditions for significant input (Carmin, 2010). Devaux (2006) analyses the influence of professional organisations on environmental issues and determines that organisations from the Soviet era with expert knowledge are still most influential. Tosun and Schulze (2015), by contrast, analysed the influence of interest groups in a very specific casecompliance with EU biofuel targets. Interestingly, their analysis indicates, first, that their influence varies within countries and, second, that biofuel producers more significantly impact the adoption of targets than environmental groups (Tosun \& Schulze, 2015).

\section{Theoretical Framework}

Keeping these significant research advancements in mind, we propose a study which applies the perspectives of civil society mobilisation and interest intermediation to post-communist energy policy-making. Before outlining our working hypotheses, we briefly elaborate on terminology. One outstanding characteristic of interest groups is their fragmented nature and heterogeneity (Eising, 2008), resulting in numerous terms such as special interest organisations, associations, lobbies, civil society organisations, social movements, civil groups, etc. Following Eising (2008), we pragmatically stick to the terms "interest groups" and "organised interests" and define them as non-state, organised groups pursuing political interests by seeking to influence political decisionmaking processes. They are characterised by three factors: "organization, political interest, and informality" (Eising, 2008, p. 5). Organisation means that they strive to "influence policy outcomes....Political interest refers to attempts...to push public policy in one direction or another on the behalf of constituencies or a general political idea" while "[i]nformality relates to the fact that interest groups do not normally seek public office but pursue 
their goals through informal interactions with politicians and bureaucrats" (Eising, 2008, p. 5). Against this background, we define influence as 'control over outcomes' to the extent that interest groups "influence outcomes in a way that brings them closer to their ideal points" (Dür \& De Bièvre, 2007, p. 3).

Yet what factors mediate the influence of interest groups on policy outcomes? Dür and De Bièvre (2007) distinguish between interest group-related, issue-related and socio-economic factors. Olson's (1971) seminal work showed how the structure and focus of interest groups may impact their means for collective action. Diffuse interests (e.g., environmental or consumer groups) may be more difficult to organise than concentrated interests (e.g., business lobbies, coal lobbies). Accordingly, size may be critical: the bigger a group, the fewer individuals may take action to achieve common interests. This implies a certain relationship between individual behaviour and group size. Olson (1971) argues that individuals' efforts to contribute to collective well-being exceed the benefits they receive in return. This creates a free-rider problem since, if there are public benefits emerging from collective action, not only individuals who actively pursued them, but also those who did not, benefit. This may encourage individuals to "free-ride" on the efforts of few. Smaller groups, in particular business interests, therefore may have an organisational advantage as they are easier to organise, monitor and control than large groups. Therefore, we hypothesise that:

H1: Concentrated organised interests wield greater clout over policy than diffuse interests due to their inherent organisational advantage.

Yet Olson's theory arguably overlooks other internal characteristics of interest groups, specifically their resources. These can encompass material aspects such as funding, but also non-material assets like public support, policy expertise and information on voters' interests and the possibilities of other policy-makers (Dür \& De Bièvre, 2007). The calculation is straightforward:

$\mathrm{H} 2$ : Organised interests with greater monetary, staffing and personnel resources wield greater clout over policy than organised interests with fewer resources.

Technical expertise may also shape policy outcomes, especially in energy policy which is ideally shaped by sound science and expertise. If an issue is technically complicated, policy-makers may require consultations with concerned organised interests (Klüver, 2011). According to Bernhagen (2012) information is a great source of lobbying power: to assess its relevance, the expected costs of information must be evaluated. Channels of influence usually include the relationships, commitments, and expected costs of policy-makers and lobbyists. Information may entail technical expertise, data on costs and citizens' preferences as well as the assessment of policy consequences. Therefore:

H3: Organised interests with specialised expertise will enjoy greater recognition and legitimacy and thus wield greater clout over policy.

Looking beyond factors inherent in interest groups, their capacity to influence policy may depend on the political and socio-economic context. Some structures may strengthen concentrated interests, others diffuse interests, while also potentially facilitating or impeding access to policy-makers. Lobbying regulations are one such factor. In systems with weak regulations, private interests, especially those with substantial resources, may more easily penetrate the policy-making apparatus.

H4: Resource-rich organised interests will wield greater clout in systems with lenient lobbying regulations, as policy-makers are more responsive to wealthy interest advocates.

Besides these conventional hypotheses, we also explore the interest intermediation systems evolving in both countries. Statism regards private groups as a disturbance to public life and builds policy-making around a strong, technocratically operating executive which seldom consults non-governmental stakeholders (Woll, 2009). Corporatism is by contrast a type of coordinated capitalism in which policy-making is transferred to semi-private organisations, generally representatives of labour and capital (Siaroff, 1999). By contrast, pluralism envisages a multiplicity of representative groups who compete for influence, form temporary alliances, and competitively pressure governments. Generally more free-market capitalist systems bring about pluralist forms of interest representation while coordinated economies (Soskice \& Hall, 2001) tend to produce corporatist structures, to the detriment of excluded interest groups.

\section{Methodological Approach}

Measuring interest group influence is notoriously complicated, as preferences may be fluid, unstable and unclearly asserted (Beyers, Eising, \& Maloney, 2008). Influence may be based on a sense of obligation, authority or respect or serve to change the "influencee's" perception of potential alternatives. Hence, decision-makers frequently base their decisions on the anticipated reactions of others. Moreover, interest groups may be less concerned with shaping policy than securing their own survival by mobilising resources (Schmitter \& Streeck, 1999). Baumgartner (2009) also argues that we must consider the status quo and difficulty of policy change. If organised interests seek to maintain a strongly embedded status quo, lobbying success may be a "non-event".

To partially overcome these difficulties, we conduct a qualitative comparative policy analysis of Hungary and 
Czechia. Both post-communist countries can be regarded as most similar cases regarding a wide range of variables (e.g., new democracies, economic transition, size, geographical position, and legacy of communist energy policy). However, they are different regarding two variables which, as outlined in our hypotheses, potentially affect the means of influence of organised interests: economic coordination and lobbying regulations. Hungary exhibits a higher degree of market coordination (Tarlea, 2017), while Czechia is a more liberal market economy (FinkHafner, 2011; McGrath, 2008). Thus, we would expect corporatist interest intermediation structures to emerge in Hungary, and more pluralist structures in Czechia, which in turn may constrain or facilitate capacity for action of interest organisations. Moreover, no encompassing lobbying regulations exist in Czechia despite many attempts to regulate lobbying (Reutter, 2012). In Hungary there has been a voluntary registry since 1994 and a far-reaching lobbying act was passed in 2006 (McGrath, 2008) ${ }^{1}$. Against this background, we secure a relatively large degree of variation along our country-specific, socio-economic variables to assess their impact on policy, while variations between interest groups operating in both countries (e.g., concentrated/diffuse, expertise, resources) enable us to assess their influence in two different settings.

Our comparative case studies rely on the preference attainment method (Dür, 2008; Dür \& De Bièvre, 2007; Howard, 2003). The method (Mahoney, 2007) entails comparing the "outcomes of political processes...with the ideal points of actors" (Dür, 2008, p. 566). We determine the initial positions of the lead ministry, the final national position and the ideal points of various interest groups. We then define influence as "the difference between two absolute differences: between a group's ideal position and the initial position of the lead ministry, and between a group's ideal position and the final national position" (Dür, 2008, p. 567). Hence, the aim is to assess whether interest groups could either shift the initial position of the lead ministry or shift the final policy position towards its ideal preferences. Our case studies aim to assess the applicability of our hypotheses in two different socio-economic settings and thus identify the causal mechanisms posing obstacles to or facilitating the attainment of preferences. Unlike a rigid statistical approach, qualitative case studies enable the in-depth, context-specific study of factors shaping the impact of interest groups, while also providing leeway for the analysis of previously unforeseen influential factors. Furthermore, comparative case studies allow us to study the process itself and how "initial conditions are translated into outcomes" (Kaarbo \& Beasley, 1999, p. 389).

We analysed a large body of qualitative data including media coverage, statements of interest groups, gov- ernment documents and secondary literature. We also conducted six interviews (three respectively in Czechia and Hungary) with organisations lobbying for and against nuclear energy. The interview partners were chosen based on a population ecology of energy interest groups, whereby the selection was narrowed down to the groups most frequently mentioned in media coverage on energy reform and who presented encompassing position papers on energy reform. We limited the number of "big energy-policy players" to 4-5 organisations per country, representing both pro- and anti-nuclear views. This enabled us to identify and contact actors who actively sought to influence energy legislation. The approximately 45-minute interviews focussed on the degree of issue-specific preference attainment (yes, no, partially) and included numerous questions pertaining to resources, expertise, and strategies of interest groups as well as the extent to which these factors were facilitative to them in attaining their own preferences and to others groups in attaining their opposing preferences. The interviews were then transcribed and coded ${ }^{2}$. Our empirical analysis is structured as follows: we first provide background information on energy policies and involved interest associations. We then descriptively outline which organisations asserted their preferences and why, before linking each hypothesis to empirical realities to address its explanatory power and weigh alternative explanations.

\section{Empirical Analysis}

\subsection{Background Information}

The 2015 Czech SEP and Hungarian NES 2030 of 2012 are the most recent energy policy frameworks, both of which focus on nuclear energy. Currently, one-third of Czech electricity production stems from NPPs. There are six operating power reactors, four in Dukovany with indefinite licences and two in Temelín. The owner and operator is $\check{C} E Z$ energetic enterprises of which nearly $70 \%$ is state-owned (World Nuclear Association, 2018b). In Hungary, almost $50 \%$ of the electricity supply is generated by NPPs. The country has four units located in Paks while a contract for two additional power reactors was signed despite an incident in 2003 during which radioactive waste polluted water and plants. The owner and operator is the state-run MVM Paks Nuclear Power Plant Ltd. (World Nuclear Association, 2018). The Czech SEP calls for an increase in nuclear capacities. It identifies support among citizens for nuclear energy despite safety concerns, as well as a preference for an energy mix and the replacement of coal energy. It targets a $50 \%$ share of nuclear sources until 2040, thus the construction of new units in already existing NPPs. It also postpones to

\footnotetext{
${ }^{1}$ For critique of its effectiveness, see Transparency International Hungary (2014a).

2 The paragraphs of transcripts served as coding units. The coding categories reflected the hypotheses, i.e., type of organisation, finances, most important issues/interests, etc. Relevant information was then extracted for the terms "(partial) success", "(partial) influence" and compared with other interview results as well as primary and secondary literature.
} 
2025 the decision on nuclear waste storage. The Hungarian NEP 2030 additionally targets the expansion of Paks and stresses the importance of nuclear energy for energy self-sufficiency.

\subsection{Energy Interest Group Landscape}

Since 1989, Czechia has experienced a reconstruction of the system of interest intermediation, whereby the number of lobbies has grown rapidly (Rakušanová, 2007) and umbrella organisations have emerged. As for nuclear energy, economic, trade and environmental associations (see Table 1.) are particularly relevant. The former represents labour and capital, creating a form of collective interest representation harmonising heterogeneous socio-economic interests into one association, while environmental associations aim to ensure the public interest in a healthy environment. Based on our overview of Czech media and policy-related literature, we categorised the most relevant actors in Czech nuclear energy into four groups: the state, more specifically the Ministry of Industry and Trade; actors associated with the state, industries and organisations favouring nuclear energy, e.g., ČEZ, Česká nukleární společnost (ČNS), State Office for Nuclear Safety (SÚJB), etc.; environmental actors, usually opposing nuclear energy such as Hnutí DUHA, Greenpeace, Jihočeské matky, Calla, Občanské Sdružení $v$ havarijní zóně, etc.; and the municipalities affected by nuclear legislation.

The transformation in Hungary was regarded as successful mainly because of the development of civil society. However, the number of interest groups has decreased (Központi Statisztikai Hivatal, 2018) and in 2003 a National Guarantee Fund was established since many organisations lacked the necessary resources to operate. Currently, scholars have also argued that semi-authoritarian structures have stunted civil society growth, a problem further compounded by their weak organisation and social embeddedness (Reutter, 2012).

Only few environmental protection interest groups exist, while economic associations are more numerous. In our overview of the policy arena, we identified several energy-related stakeholders: the Government and the Ministry of Development; state-associated or pronuclear energy institutions: MVM, Hungary's National Atomic Energy Committee (OAB), Hungarian Atomic Energy Authority (HAEA) etc.; actors usually opposing nuclear energy such as Greenpeace, Energiaklub; and finally, municipalities. Before evaluating the factors affecting the influence of interest groups, we address whether they were able to attain their preferences based on a distinction between nuclear supporters and opponents. Supporters, usually industrial interests, emphasise benefits over risks while opponents represented by environmental groups (see Table 2.) highlight risks (Sarlós, 2015). Overall, the ministry belongs to the former.

\subsection{Preference Attainment Analysis}

The main goals of the Czech energy policy were security, export competitiveness and self-sufficiency, whereby new nuclear reactors are supposed to reduce greenhouse gases (International Energy Agency, 2016). The initial position of the lead ministry was to increase the

Table 1. Environmental stakeholders in Czechia, information based on interest groups websites.

\begin{tabular}{lllll}
\hline Actor (and founding) & Staff & Volunteers & Finances & Members \\
\hline Jihočeské matky (1992) & 3 & yes & $42,700 €$ & n.a. \\
\hline Hnutí DUHA (Praha) (1989) & 40 & yes & $600,000 €$ & n.a. \\
\hline Calla (1991) & 2 & yes & $75,000 €$ & 30 \\
\hline Greenpeace Česká republika (1990) & 17 & yes & $560,000 €$ & n.a. \\
\hline Občanské Sdružení v havarijní zóně (2001) & n.a. & n.a. & n.a. & n.a. \\
\hline Centrum pro dopravu a energetiku (2000) & 6 & n.a. & $30,000 €$ & n.a. \\
\hline Glopolis (2004) & 22 & n.a. & $512,000 €$ & n.a. \\
\hline
\end{tabular}

Table 2. Environmental stakeholders in Hungary, information based on interest groups websites.

\begin{tabular}{lllll}
\hline Actor (and founding) & Staff & Volunteers & Finances & Members \\
\hline Energiaklub (1992) & 24 & 10 & $118,011 €$ & 30 \\
\hline Magyar Természetvédők Szövetsége (1989) & 19 & Yes & $150,000 €$ & $100+$ \\
\hline Levegó Munkacsoport (1988) & 75 & 47 & $54,000 €$ & $60+$ HU NGOs \\
\hline Greenpeace Hungary (2002) & 19 & 100 & $900,000 €$ & n.a. \\
\hline Zöld Kapcsolat Egyesület (2005) & 7 & 32 & $18,000 €$ & 12 \\
\hline
\end{tabular}


share of nuclear energy usage by $10 \%$ (D. Burket, personal communication, August 7,2018 ) and then $50 \%$ by 2040 (Nachmany et al., 2015). To this end, the $2015 \mathrm{Na}$ tional Action Plan called for the construction of new NPP units. The position of the pro-nuclear coalition was thus very close to the legislation adopted while the ideal position of anti-nuclear movements was partly against any new NPPs. ČEZ, for example, has strong leverage over energy policy and actively lobbies (Schwartzkopff, Schulz, \& Goritz, 2017). Since the company is state-owned, the state assesses the impact of potential legislation on the company (Osička \& Černoch, 2017, p. 12). Thus, the SEP emerged from cooperation between the government and ČEZ (K. Polanecký, personal communication, August 1, 2018), while ČEZ also strongly lobbies for the EU emission trading system. To promote a non-carbon transition in line with EU directives, it advocates more nuclear energy (Schwartzkopff et al., 2017). ČNS also pushed for the expansion of NPPs, and even was allowed to co-draft some of the laws (D. Burket, personal communication, August 7, 2018).

Environmental groups, by contrast, mainly pushed to stop nuclear energy usage and include renewables into policies. The former extreme position was not attained, while renewables were indeed taken into account. The state argued that the complete abandonment of nuclear energy is not yet possible because other sources could not meet national energy demands. The state therefore sought to compensate the elimination of coal-based energy with increased nuclear energy. Hence, environmental groups opposing nuclear energy were perceived as a "complication" and excluded from policy-making. Therefore, the state required additional technical expertise on nuclear energy and only enabled pro-nuclear groups to engage in decision-making (E. Sequens, personal communication, July 19, 2018).

However, opponents did succeed in generating media attention and bringing anti-nuclear positions into the political debate. Beyond the SEP, they were successful regarding nuclear waste storage legislation as Calla claims. Together with municipalities that were chosen as candidates for nuclear waste storage, Calla pushed through a law to include municipalities when deciding on the construction of storage places. The channels of influence were meetings with parliamentarians who actively pursued the goal. Mayors were then authorised to express their opinions on the underground storage of nuclear waste. Renewables and coal mining reductions also made their way into the SEP. Here channels of influence can be traced back rather to the Ministry of Industry and Trade, especially the Standing Committee on Nuclear Energy, where interest groups are more frequently incorporated (E. Sequens, personal communication, July 19, 2018). Since renewable energy is only developing very slowly, organisations aim to revive the debate and include renewables in the SEP as example models. However, environmental organisations generally faced enormous difficulties in asserting their preferences, a main reason being delays in the policy process. Also neither ecological organisations nor nuclear energy opponents were permitted to participate within the Czech National Action Plan for the Development of the Nuclear Energy. This hindered their access to governmental material during the decision-making phase "behind closed doors" (E. Sequens, personal communication, July 19, 2018).

The Hungarian NES 2030 targets "a sustainable and secure energy sector while supporting the competitiveness of the economy" (International Energy Agency, 2017, p. 9). It aims for energy security and efficiency, a greater share of renewables, the preservation of the current nuclear capacity and decarbonising while exploiting nuclear power. The country plans to increase the share of $52 \%$ of the already generated electricity by adding at least two more units to Paks and building a new power plant Paks II (Gallai et al., 2015). The decision was framed as a guarantee for self-sufficiency and independence since Hungary highly depends on energy imports (Schulz, Amon, Goritz \& Schwartzkopff, 2017). The Ministry of National Development was the main actor in the policy formulation process (International Energy Agency, 2017), thus giving the government extensive clout. Nevertheless, NGOs like Energiaklub, the Clean Air Action Group (Levegő Munkacsoport, 2015) and Greenpeace pushed for a transition towards renewables-while some even outright rejected nuclear energy (Levegő Munkacsoport, 2015). However, organisations with positions diverging from the official state position face difficulties: if a group supports the official position, it is easier to successfully advocate one's own position. By contrast, groups neutral or not favouring the position of the stakeholder in power face difficulties or even outright rejection when pursuing their own interests. Hence, contrary to the generally corporatist policy-making structures in Hungary, energy decision-making structures are rather statist and impenetrable because only interest groups close to the state are strongly incorporated. Environmental groups are given space to express themselves to maintain legitimacy, but they generally have failed to attain their preferences and policy ideals (P. Zagyvai, personal communication, August 30, 2018).

Like in Czechia, it is difficult to distinguish between the initial and final national position in Hungary, as the government had a strong position that it rapidly pursued without civil society consultations. Hence, neither in the policy-definition nor policy-formulation process were there open channels for nuclear opponents. Thus in Kitschelt's terminology political opportunity structures are relatively closed on the input side (1986). Other sources even claim the state holds an energy policy monopoly (Méltányosság Politikaelemző Központ \& Energiaklub, 2011). For example, the parliament was not seriously included in the Russian-Hungarian deal to construct Paks II. Negotiations were short, while many parliamentarians learned about it from the press only (Nagy, 2014). The nuclear lobby, by contrast, was heavily involved in the preparation process as the MVM worked 
on the issue for two years, prompting claims of "strategic arrangements between the government and corporations" (Transparency International Hungary, 2014b). The policy was thus crafted without regard to public opinion (Perger, 2009).

Hungarian energy negotiations are held in "high politics" expert circles, while opponents of government policy are largely excluded or only have the opportunity to express opinions on nearly finalised legislation (A. Perger, personal communication, July 26, 2018; P. Zagyvai, personal communication, August 30,2018 ). Thus, both environmental and anti-nuclear groups assess their degree of preference attainment rather negatively to the extent they were indeed able to raise awareness, initiate discussions and draw attention to the problems of nuclear energy. However, they failed to substantially push decisions in their preferred direction and could not influence the Paks II agreement (A. Perger, personal communication, July 26, 2018; P. Zagyvai, personal communication, August 30,2018 ).

\subsection{Assessing the Hypotheses}

How did our hypotheses match up against empirical events? We assumed that interest groups rich in financial, staffing and personnel resources are likely to be more powerful, especially when lobbying regulations are lenient. Our interviews revealed that financial resources indeed generated higher levels of activity in both countries and secured the further employment of staff, thus ensuring organisational survival. Finances were insofar relevant as they also enabled interest groups to employ experts to analyse legislative proposals, facilitate access to information and create information material (D. Burket, personal communication, August 7, 2018; P. Zagyvai, personal communication, August 30, 2018). However, the preference attainment analysis shows that these factors matter only up to a certain point, whereby we again have to distinguish between industrial and environmental groups. In general, the latter have fewer funds available. Yet despite their failure to research their far-fetched goals such as abolishing nuclear energy, organisations like Hnutí DUHA influenced some less central aspects of the Czech SEP. They were invited to comment on the SEP especially in the fine-tuning phase and tried to raise awareness for renewables. Specifically, they submitted example models on how to implement a sustainable energy plan (K. Polanecký, personal communication, August 1,2018$)$. By contrast, with even fewer personnel and financial resources Calla was unsuccessful in reducing nuclear energy usage, but together with municipalities succeeded in tackling the issue of nuclear waste. Specifically, municipalities must agree on the construction of a new storage places and at this stage, Calla steps in (E. Sequens, personal communication, July 19, 2018).

While some supporters of nuclear energy, e.g., ČNS, have even smaller annual budgets, they participated in drafting the policy. This was facilitated by their strong media presence and personal contacts as individuals within groups have often been acquainted for many years. Hence, access proved easier if long-lasting personal ties exist (D. Burket, personal communication, August 7, 2018; K. Polanecký, personal communication, August 1, 2018). In Hungary, Greenpeace has even more funds and personnel, but achieved little success because the Hungarian government proved impenetrable for opposing groups (A. Perger, personal communication, July 26, 2018). Industrial actors as well as the ČEZ and the MVM not only have more resources, but are also partly state-owned and have been incorporated in the policymaking process for a long time. Thus, although groups lacking resources were at a disadvantage, we determined no direct link between resources and preference attainment. However, resources did enable higher levels of activity such as funding environmental protection projects or requests for independent analyses, while more personnel also enabled the recruitment experts to assess issues or policy drafts (P. Zagyvai, personal communication, August 30, 2018). Gallai et al. (2015) suggest that in Hungary financial resources were only partially relevant, but acknowledged that larger organisations are very successful. Therefore, the first hypothesis can be partially confirmed.

We also found that specialised expertise facilitated preference attainment but is only relevant when interest groups have already established access to decisionmakers and are recognised in higher circles. All groups in both countries claim to provide policy-makers with specialised expertise. However, there is a difference in the type of information: groups providing technical or physical expertise such as research institutions enjoyed greater recognition while interests groups focusing on environmental issues like renewables were less influential. Expertise on renewables influenced public debates and was more acknowledged by Czech authorities (K. Polanecký, personal communication, August 1, 2018). ČNS even identified a shift in information demand: while several years ago, technical information was more significant, demands for economic and legal information have increased (D. Burket, personal communication, August 7, 2018). Research on Hungary also stresses the importance of expertise (Gallai et al., 2015) and Greenpeace Hungary suggests they indeed aimed to exchange information with policy-makers and conducted case studies. However, they could not shape policy-all proposals were heard but later reformulated. Especially in the case of Paks II, Energiaklub answered questions, gave opinions and after consultations with the ministry, the parliament entirely rewrote the proposal. The suggestion to build a new NPP, that was originally not included, was newly added (A. Perger, personal communication, July 26, 2018). By contrast, technical information from research institutes was specifically demanded frequently (P. Zagyvai, personal communication, August 30, 2018). These findings fall in line with previous research which suggests that the nuclear energy discourse was 
conducted in a highly technical manner in closed communities (Osička \& Černoch, 2017), thus limiting public participation (Ocelík et al., 2017). The same generally applies for Hungary (Vari \& Ferencz, 2007). The antinuclear lobby met a dead-end when providing information and only succeeded in adding various new details to legislation on nuclear waste storage or expanding renewables. Altogether, in both countries environmental groups had weaker influence than industrial groups because they lacked the capacity to mobilise despite being smaller. Somewhat counterintuitively to the collective action dilemma (Olson, 1971), these smaller groups seem to miss the chance to influence the outcomes while larger industrial groups have much greater leverage over policy. Generally, the ideal positions of supporters and the position of the lead ministry match while nuclear opponents only exerted complimentary influence i.e., they brought opposing positions into debates or achieved small concessions e.g. the inclusion of municipalities into decision-making and upholding the debate on renewables. The same pattern can be observed when comparing the final national position with the ideal positions of pro- and anti-nuclear groups. Industrial groups were able to attain their preferences while environmental groups exerted negative influence by "hindering decisions or their implementation, or preventing an issue from being put on the policy agenda" (Gallai et al., 2015, p. 1484).

We also hypothesised that groups representing concentrated interests are more successful in preference attainment because it is easier to mobilise their members (Olson, 1971). Contrarily, our empirical findings show that ČEZ collaborated with the government during the preparation phase of the SEP (K. Polanecký, personal communication, August 1, 2018). Smaller and concentrated interests such as Calla only had minor success, e.g. they could not completely stop the construction of new NPPs but did secure the inclusion of municipalities into the decision-making process on nuclear waste management (E. Sequens, personal communication, July 19, 2018).

Interview partners, alternatively, contended that membership is a crucial prerequisite for preference attainment. Membership can be twofold: first, interest groups may have individual and corporate members; second, interest groups themselves may be members of larger groups i.e. umbrella groups. In Czechia, there were only few members in the least influential groups, while e.g. ČNS had strong pro-nuclear membership consisting of large corporations as well as many volunteers promoting nuclear energy (D. Burket, personal communication, August 7, 2018). Even though all groups are members of umbrella organisations, their level of activity i.e. membership in more and larger umbrella groups either on the European or international level is critical. In Hungary the same applies: according to Gallai et al. (2015), large membership, networks and cooperation with other organised interests and positions that correspond with those of the government and media have a high explana- tory value. Therefore the level of activity in pursuing interests is an important factor: as already mentioned, groups like the ČNS or Hnutí DUHA in Czechia participated either in the drafting phase of the SEP (D. Burket, personal communication, August 7, 2018) or by including renewables into the policy in the latter case (K. Polanecký, personal communication, August 1, 2018). By contrast, Calla, which has fewer members and is not represented in many umbrella organisations, only achieved success on the local level (E. Sequens, personal communication, July 19, 2018). Similarly in Hungary, Greenpeace cooperates only occasionally with likeminded groups and has little influence. This lack of cooperation is due to the organisation's philosophy-it operates with voluntary independent donations. They accept neither private funds nor financing from the government, governmental organisations (e.g., Visegrád fund) or the EU in order to remain independent and neutral. Therefore, they collaborate only on specific projects since some donors expect certain results and the organisation often cannot cooperate with other groups (A. Perger, personal communication, July 26, 2018).

\subsection{Interest Intermediation Structures in Comparison}

What general conclusions can we draw regarding interest intermediation structures? As noted above, Hungary exhibits stronger market coordination (Tarlea, 2017) and lobbying regulations, while Czechia is a more liberal market economy with weaker lobbying regulations (FinkHafner, 2011; McGrath, 2008). Contrary to a generally more pluralist and unregulated interest group environment in Czechia, energy policy-making remains highly statist and technocratic (E. Sequens, personal communication, July 19, 2018) with the direct incorporation of nuclear energy enterprises such as ČEZ (D. Burket, personal communication, August 7, 2018). There are, however, signs of emerging corporatism as it was possible for other groups to participate in debates on or in the fine-tuning of already decided policies (K. Polanecký, personal communication, August 1, 2018). Thus altogether, we observe a combination of (more pronounced) statist and (weaker) corporatist features (D. Burket, personal communication, August 7, 2018).

Hungarian energy policy-making appears to be more open to civil society, as the public can attend hearings and present opinions. However, these democratic participative elements have their limits (P. Zagyvai, personal communication, August 30, 2018). After the draft prepared in expert circles is ready, there is a very limited timespan for expressing opinions (on highly technical issues). Thus interests are generally defined by state-owned companies and expert groups, thus creating unequal participation opportunities (A. Perger, personal communication, July 26, 2018). Interestingly, in the preparation process, participants are invited, most of whom are experts while external stakeholders are not included. The information reaches them only after the 
decision has almost been taken. Afterwards, civil surveillance is granted only to citizens with technical knowledge. Also, many groups wishing to participate do not have the resources necessary to analyse an extensive draft (P. Zagyvai, personal communication, August 30, 2018). Thus corporatist structures exist, but policy-making remains highly centralised and technocratic (Aalto et al., 2017). We also hypothesised that resource-rich organisations in systems with lenient lobby regulations might exert more influence. However, the existence of lobby regulations matters little as structures and developments are rather determined by the state and not interest groupsat least in energy policy.

\section{Conclusions}

In this article, we put together a set of factors to analyse the mobilisation capacity and impact of interest groups on post-communist energy policies. Our general finding is that strong state-industrial alliances persist in both cases, which clearly enabled supporters of nuclear energy to attain their preferred positions. They closely cooperated with state policy-makers in designing nuclear policies, making it difficult to distinguish the exact positions of the state and the interest groups. Despite this overarching finding, it also became apparent that civil society groups (i.e., renewable energy and environmental groups) indeed demonstrate strong signs of mobilisation capacity and that various forums have emerged enabling them to at least voice their demands. This has resulted in numerous "cracks" in the state-industrial alliances, allowing environmental groups at least to make modest modifications or corrections to pre-determined policies. In other words, preference attainment is issuespecific to the extent that even smaller, non-industrial NGOs may achieve less bold objectives which do not alter the pro-nuclear status quo (e.g., commitments to expand renewables, coal mining limits, regulations on municipality inclusion regarding decisions on nuclear waste storage). Thus, in Kitschelt's terminology, the Czech and Hungarian energy policy opportunity structures cannot be considered entirely closed to civil society mobilisation and input, but are more selectively open to those pursuing state-favoured policies.

Beyond this general finding, we also determined that financial and personnel resources are not necessarily automatically predictors of preference attainment. In both countries, poorly equipped pro-nuclear actors were also able to exercise influence to the extent that they were backed by strong industrial lobbies. As for Olson's (1971) classic hypothesis on concentrated and diffuse interests, we found membership in organisational associations and umbrella organisations to be more significant than the type of interest being pursued. Our hypothesis regarding specialised expertise was also only partially confirmed in these two cases. Interest groups must already have access to decision-makers to be able to provide them with expertise. Thus, the precondition for providing informa- tion is essentially incorporation into state-industrial policy alliances.

Regarding interest intermediation constellations, the energy sectors of both countries exhibit a mixture of corporatist and statist features. Decision-making is not very transparent and participation opportunities are unequal since some groups have little access to policy-making. This in turn has proven to be an impediment to pluralist political competition and progressive policy change (i.e., towards renewable energy).

Where should this research agenda now be taken? We admit that our study bears numerous methodological constraints. Most notably, the technical nature of nuclear energy and strongly embedded status quo somewhat distort the generalisability of our findings, a problem further compounded by our limitation to two countries. Therefore, we argue that future research should focus on other aspects of CEE energy policy (e.g., coal, oil, energy efficiency) and other countries. We also believe that research on the region could benefit from new approaches in interest group research, which focus on novel variables such as the size of lobbying coalitions (Klüver, 2011) or the professionalisation of CEE interest groups through interactions with EU peers. Finally, given the methodological shortcomings of our qualitative approach to interest groups, scholars should engage with the quantitative, survey-based analysis of interest group influence by incorporating a broader range of variables to explain lobbying success.

\section{Acknowledgments}

The research was conducted as a part of the research project "The "Missing Link": Examining organized interests in post-communist policy making" of the Goethe University Frankfurt am Main, Germany and the University of Opole, Poland funded by the Beethoven 2-PolishGerman Funding Initiative of the Deutsche Forschungsgemeinschaft and Narodowe Centrum Nauki.

\section{Conflict of Interests}

The authors declare no conflict of interests.

\section{References}

Aalto, P., Nyyssönen, H., Kojo, M., \& Pal, P. (2017). Russian nuclear energy diplomacy in Finland and Hungary. Eurasian Geography and Economics, 58, 386-417. https://doi.org/10.1080/15387216.2017. 1396905

Ágh, A. (1996). Meso-politics in Central Europe fighting with the infantile disease in Europeanization and democratization. Parliaments and organised interests: The second steps (pp. 241-252). Budapest: Hungarian Centre for Democracy Studies.

Andersen, S. S., Goldthau, A., \& Sitter, N. (2017). Energy union: Europe's new liberal mercantilism? Inter- 
national political economy series. London: Palgrave.

Avdagic, S. (2005). State-labour relations in East Central Europe: Explaining variations in union effectiveness. Socio-Economic Review, 3, 25-53. https://doi.org/ 10.1093/SER/mwh012

Bakos, G. (2001). Privatizing and liberalizing electricity, the case of Hungary. Energy Policy, 29, 1119-1132.

Balmaceda, M. M. (2002). EU energy policy and future European energy markets: Consequences for the Central and East European states. Mannheim: MZES.

Baumgartner, F. R. (2009). Lobbying and policy change: Who wins, who loses, and why. Chicago, IL: University of Chicago Press.

Bernhagen, P. (2012). When do politicians listen to lobbyists (and who benefits when they do)? European Journal of Political Research, 52, 1-24. https://doi.org/ 10.1111/j.1475-6765.2012.02062.x

Beyers, J., Eising, R., \& Maloney, W. (2008). Researching interest group politics in Europe and elsewhere: Much we study, little we know? West European Politics, 31, 1103-1128. https://doi.org/10.1080/ 01402380802370443

Binderkrantz, A. S., Christiansen, P. M., \& Pedersen, H. H. (2014). A privileged position? The influence of business interests in government consultations. Political Research Quarterly, 24, 879-896. https://doi.org/ 10.1093/jopart/muu028

Binderkrantz, A. S., \& Rasmussen, A. (2015). Comparing the domestic and the EU lobbying context. Journal of European Public Policy, 22, 552-569. https://doi.org/10.1080/13501763.2015.1008553

Binhack, P., \& Tichý, L. (2012). Asymmetric interdependence in the Czech-Russian energy relations. Energy Policy, 45, 54-63. https://doi.org/10.1016/ j.enpol.2012.01.027

Bunea, A. (2013). Issues, preferences and ties: Determinants of interest groups' preference attainment in the EU environmental policy. Journal of European Public Policy, 20, 552-570. https://doi.org/10.1080/ 13501763.2012.726467

Carmin, J. (2010). NGO capacity and environmental governance in Central and Eastern Europe. Acta Politica, 45, 183-202. https://doi.org/10.1057/ap.2009.21

Císař, O., \& Vráblíková, K. (2013). Transnational activism of social movement organizations: The effect of European Union funding on local groups in the Czech Republic. European Union Politics, 14, 140-160. https://doi.org/10.1177/1465116512456311

Crouch, C. (2004). Post-democracy. Themes for the 21st century: 2004: 1. Cambridge: Polity.

Dahl, R. A. (1971). Polyarchy. New Haven, NJ: Yale University Press.

Devaux, S. (2006). Old networks, new roles? The role of environmental think tanks in the Czech Republic. Perspectives on European Politics and Society, 7, 221-235. https://doi.org/10.1080/ 15705850600840072

Dür, A. (2008). Measuring interest group influence in the EU. European Union Politics, 9, 559-576. https:// doi.org/10.1177/1465116508095151

Dür, A., \& De Bièvre, D. (2007). The question of interest group influence. Journal of Public Policy, 27, 1-12. https://doi.org/10.1017/S0143814X07000591

Eising, R. (2008). Interest groups in EU policy-making. Living Reviews in European Governance, 3(4). Retrieved from http://edoc.vifapol.de/opus/volltexte/ 2011/2484

Fagan, A., \& Kopecký, P. (2017). The Routledge handbook of East European politics (1st ed.). Milton: Taylor \& Francis.

Fink-Hafner, D. (1998). Organized interests in the policy-making process in Slovenia. Journal of European Public Policy, 5, 285-302. https://doi.org/ 10.1080/135017698343992

Fink-Hafner, D. (2011). Interest representation and postcommunist parliaments over two decades. The Journal of Legislative Studies, 17, 215-233. https:// doi.org/10.1080/13572334.2011.574027

Frantál, B., \& Malý, J. (2017). Close or renew? Factors affecting local community support for rebuilding nuclear power plants in the Czech Republic. Energy Policy, 104, 134-143. https://doi.org/10.1016/ j.enpol.2017.01.048

Gallai, S., Döme, Z., Molnár, B., \& Reich, J. (2015). What makes them successful? Influential interest groups in Hungary (1990-2014). Europe-Asia Studies, 67, 1469-1486. https://doi.org/10.1080/ 09668136.2015.1088514

Guasti, P. (2016). Development of citizen participation in Central and Eastern Europe after the EU enlargement and economic crises. Communist and PostCommunist Studies, 49, 219-231. https://doi.org/ 10.1016/j.postcomstud.2016.06.006

Hellman, J. S. (1998). Winners take all: The politics of partial reform in post-communist transitions. World Politics, 50, 203-234. https://doi.org/10.1017/ S0043887100008091

Howard, M. M. (2003). The weakness of civil society in post-Communist Europe (2nd ed.). Cambridge: Cambridge University Press.

International Energy Agency. (2016). Energy policies of IEA countries Czech Republic 2016 review. Retrieved from https://www.iea.org/countries/ membercountries/czechrepublic

International Energy Agency. (2017). Energy policies of IEA Countries. Hungary 2017 review. Retrieved from https://webstore.iea.org/energy-policies-ofiea-countries-hungary-2017-review

Kaarbo, J., \& Beasley, R. K. (1999). A practical guide to the comparative case study method in political psychology. Political Psychology, 20(2), 369-391.

Kitschelt, H. P. (1986). Political opportunity structures and political protest: Anti-nuclear movements in four democracies. British Journal of Political Science, 16(1), 57-85.

Klüver, H. (2009). Measuring interest group influence 
using quantitative text analysis. European Union Politics, 10, 535-549. https://doi.org/10.1177/ 1465116509346782

Klüver, H. (2011). The contextual nature of lobbying: Explaining lobbying success in the European Union. European Union Politics, 12, 483-506. https://doi.org/ $10.1177 / 1465116511413163$

Klüver, H. (2013). Lobbying as a collective enterprise: Winners and losers of policy formulation in the European Union. Journal of European Public Policy, 20(1), 59-76.

Központi Statisztikai Hivatal. (2018). STADAT-3.2.13. Number, distribution and total revenues of nonprofit organisations by community types (2005-). Retrieved from http://www.ksh.hu/pls/ksh/docs/ eng/xstadat/xstadat_annual/i_qpg003.html

Kubik, J. (2005). How to study civil society. East European Politics and Societies, 19, 105-120. https:// doi.org/10.1177/0888325404272556

Levegő Munkacsoport. (2015). Hungarian energy policy: An assessment. Budapest: Levegő Munkacsoport. Retrieved from https://www.levego.hu/sites/ default/files/hungarian_energy_policy-honlapra.pdf

Mahoney, C. (2007). Lobbying success in the United States and the European Union. Journal of Public Policy, 27, 35. https://doi.org/10.1017/ S0143814X07000608

McGrath, C. (2008). The development and regulation of lobbying in the new member states of the European Union. Journal of Public Affairs, 8, 15-32. https://doi.org/10.1002/pa.284

Méltányosság Politikaelemző Központ, \& Energiaklub. (2011). A második Orbán-kormány energiapolitikája [The energy policy of the second Orbán government]. Retrieved from http://energiakontrollprogram.hu/ tanulmany/a-masodik-orban-kormany-energiapolitik aja

Minin, N., \& Vlček, T. (2018). Post-Fukushima performance of the major global nuclear technology providers. Energy Strategy Reviews, 21, 98-110. https://doi.org/10.1016/j.esr.2018.05.006

Ministerstvo průmyslu a obchodu. (2015). Aktualizace Státní energetické koncepce České republiky [Update of the State Energy Policy of the Czech Republic]. Praha: Ministerstvo prümyslu a obchodu. Retrieved from https://www.mpo.cz/en/energy/stateenergy-policy/state-energy-policy-233258

Nachmany, M., Fankhauser, S., Davidová, J., Kingsmill, N., Landesman, T., Roppongi, H., ... Singleton, C. S. (2015). The 2015 global climate legislation study. A review of climate change legislation in 99 countries: Summary for policy-makers. London: Grantham Research Institute on Climate Change and the Environment, GLOBE International.

Nagy, A. T. (2014). Paks II a parlamentben [Paks II in the parliament]. Méltányosság Politikaelemző Központ. Budapest: Méltányosság Politikaelemző Központ.

Nemzeti Fejlesztési Minisztérium. (2012). Nemzeti
Energiastratégia 2030 [National Energy Strategy 2030]. Budapest: Nemzeti Fejlesztési Minisztérium. Retrieved from http://2010-2014.kormany.hu/ download/4/f8/70000/Nemzeti\%20Energiastrat\%C3 \%A9gia\%202030\%20teljes\%20v\%C3\%A1ltozat.pdf

Ocelík, P., Osička, J., Zapletalová, V., Černoch, F., \& Dančák, B. (2017). Local opposition and acceptance of a deep geological repository of radioactive waste in the Czech Republic: A frame analysis. Energy Policy, 105, 458-466. https://doi.org/10.1016/j.enpol. 2017.03.025

Olson, M. (1971). The logic of collective action: Public goods and the theory of groups (Rev. ed.). Cambridge: Harvard University Press.

Osička, J., \& Černoch, F. (2017). Anatomy of a black sheep: The roots of the Czech Republic's pro-nuclear energy policy. Energy Research \& Social Science, 27, 9-13. https://doi.org/10.1016/j.erss.2017.02.006

Pérez-Solórzano Borragán, N. (2006). Post-Communist interest politics: A research agenda. Perspectives on European Politics and Society, 7, 134-154. https://doi.org/10.1080/15705850600839868

Perger, A. (2009). New build in Hungary: More questions than answers. WISE International. Retrieved from https://wiseinternational.org/nuclear-monitor/696/ new-build-hungary-more-questions-answers

Petrova, T., \& Tarrow, S. (2007). Transactional and participatory activism in the emerging European polity: The puzzle of East-Central Europe. Comparative Political Studies, 40, 74-94. https://doi.org/10.1177/ 0010414006291189

Pleines, H. (2011). Weakness as precondition of smooth integration? Representation strategies of functional interest groups from new member states at the EU level. Journal of European Integration, 33, 507-521. https://doi.org/10.1080/07036337.2011.582286

Rakušanová, P. (2007). Povaha občanské společnosti v České republice v kontextu strední Evropy [The character of civil society in the Czech Republic in the context of Central Europe]. Praha: Sociologický ústav AV Čr.

Ramet, S. P. (2010). Central and southeast European politics since 1989. Cambridge: Cambridge University Press.

Reutter, W. (2012). Verbände und Interessengruppen in den Ländern der Europäischen Union [Associations and interest groups in the countries of the European Union]. Wiesbaden: VS.

Sarlós, G. (2015). Risk perception and political alienism: Political discourse on the future of nuclear energy in Hungary. Central European Journal of Communication, 1(14), 93-111.

Schmitter, P. C., \& Streeck, W. (1999). The organization of business interests (MPIfG discussion paper). Köln: MPIFG.

Schneider, G., \& Baltz, K. (2003). The power of specialization: How interest groups influence EU legislation. Rivista di Politica Economica, 93(1), 1-31. 
Schulz, S., Amon, A., Goritz, A., \& Schwartzkopff, J. (2017). Climate and energy snapshot: Hungary (Briefing Paper). London, Brussels, Berlin and Washington: E3G. Retrieved from https://www.e3g.org/ library/climate-energy-snapshot-hungary

Schwartzkopff, J., Schulz, S., \& Goritz, A. (2017). Climate and energy snapshot: Czech Republic. (Briefing Paper). London, Brussels, Berlin and Washington: E3G. Retrieved from https://www.e3g.org/ library/climate-energy-snapshot-czech-republic

Siaroff, A. (1999). Corporatism in 24 industrial democracies: Meaning and measurement. European Journal of Political Research, 36, 175-205. https://doi.org/ 10.1111/1475-6765.00467

Soskice, D. W., \& Hall, P. A. (2001). Varieties of capitalism: The institutional foundations of comparative advantage. Oxford: Oxford University Press.

Stark, D., \& Bruszt, L. (1998). Postsocialist pathways: Transforming politics and property in East Central Europe. Cambridge: Cambridge University Press.

Szulecki, K. (2018). Conceptualizing energy democracy. Environmental Politics, 27, 21-41.

Szulecki, K., Fischer, S., Gullberg, A. T., \& Sartor, O. (2016). Shaping the 'Energy Union': Between national positions and governance innovation in EU energy and climate policy. Climate Policy, 16, 548-567. https://doi.org/10.1080/14693062.2015.1135100

Tarlea, S. (2017). Higher education governance in Central and Eastern Europe: A perspective on Hungary and Poland. European Educational Research Journal, 16, 670-683. https://doi.org/10.1177/ 1474904116677756

Tosun, J., \& Schulze, K. (2015). Compliance with EU biofuel targets in South-Eastern and Eastern Europe: Do interest groups matter? Environment and Planning C: Government and Policy, 33, 950-968. https://doi.org/10.1177/0263774X15605923

Transparency International Hungary. (2014a). Cam- paign spending in Hungary: Total eclipse. Budapest: Transparency International Hungary. Retrieved from https://transparency.hu/wp-content/uploads/2016/ 02/Total-Eclipse-Campaign-Spending-in-HungaryStudy.pdf

Transparency International Hungary. (2014b). Lobbying. Retrieved from https://transparency.hu/en/ kozszektor/lobbizas

Vándor, P., Traxler, N., Millner, R., \& Meyer, M. (Eds.). (2017). ERSTE Stiftung studies. Civil society in Central and Eastern Europe: Challenges and opportunities. Vienna: ERSTE Stiftung.

Vari, A., \& Ferencz, Z. (2007). Radioactive waste management in Hungary: Changing approaches and conflicts. Journal of Environmental Assessment Policy and Management, 9, 185-209. https://doi.org/10.1142/ S1464333207002767

Vlček, T., \& Černoch, F. (2013). The energy sector and energy policy of the Czech Republic. Brno: Masarykova univerzita.

Vráblíková, K. (2009). Politická participace a její determinanty $v$ postkomunistických zemích [Political participation and its determinants in post-communist countries]. Czech Sociological Review, 45, 867-898.

Woll, C. (2009). The demise of statism: Associations and the transformation of interest intermediation in France. In S. Brouard (Ed.), The French fifth republic at fifty: Beyond stereotypes (pp. 226-244). Basingstoke: Palgrave.

World Nuclear Association. (2018a). Nuclear power in Hungary. World Nuclear Association. Retrieved from http://www.world-nuclear.org/information-library/ country-profiles/countries-g-n/hungary.aspx

World Nuclear Association. (2018b). Nuclear power in the Czech Republic. World Nuclear Association. Retrieved from http://www.world-nuclear.org/ information-library/country-profiles/countries-a-f/ czech-republic.aspx

\section{About the Authors}

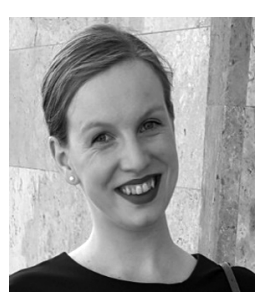

Brigitte Horváthová is Research Assistant and PhD candidate at the Goethe University of Frankfurt. She specialises in policy analysis and focusses on environmental, energy and healthcare policies, Central and Eastern European countries, Europeanisation and democracy research. She is a collaborator in the research project "The 'Missing Link': Examining organized interests in post-communist policy-making" funded by the German DFG and Polish NCN.

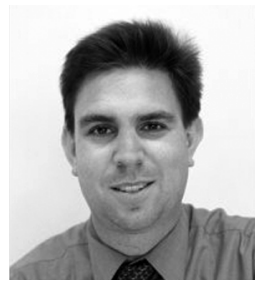

Michael Dobbins is Assistant Professor of policy analysis at the Goethe University of Frankfurt and interim professor of public administration at the University of Konstanz. His doctoral thesis dealt with higher education in Central and Eastern Europe. His main areas of research are higher and secondary education policy and post-communist transformation processes. He is the co-director of the research project "The 'Missing Link': Examining organized interests in post-communist policy-making" funded by the German DFG and Polish NCN. 